\title{
Comments on: "Case reports and research productivity among Syrian medical students: Review, reality, and suggested solutions"
}

The Editor, We would like to address the feedback we received from some readers concerning our recently published article, "Case reports and research productivity among Syrian medical students: Review, reality, and suggested solutions" published in OctoberDecember 2015 issue of Avicenna Journal of Medicine. 


\begin{tabular}{|c|c|c|c|}
\hline Journal name & Institution & $\begin{array}{c}\text { Year of } \\
\text { publication }\end{array}$ & Title \\
\hline Clinical and Experimental Dermatology & $\begin{array}{l}\text { Dermatology Department, Tishreen } \\
\text { Hospital, Damascus, Syria }\end{array}$ & 1997 & $\begin{array}{l}\text { Topical glyceryl trinitrate: A possible treatment for } \\
\text { cutaneous leishmaniasis }\end{array}$ \\
\hline The Journal of Heart Valve Disease & $\begin{array}{l}\text { Damascus University Cardiovascular } \\
\text { Surgical Center, Syria }\end{array}$ & 2000 & $\begin{array}{l}\text { The mitral pulmonary autograft: A follow-up } \\
\text { cautionary report }\end{array}$ \\
\hline Endoscopy & $\begin{array}{l}\text { Division of Gastroenterology, Saint Louis } \\
\text { Hospital,Aleppo, Syria }\end{array}$ & 2002 & $\begin{array}{l}\text { Endoscopic discovery of a Taenia in the duodenal } \\
\text { bulb }\end{array}$ \\
\hline Dermatology Online Journal & Ministry of Health, Syria-Hama & 2006 & Plate-like cutaneous osteoma on the scalp \\
\hline Dermatology Online Journal & Ministry of Health, Syria-Hama & 2003 & $\begin{array}{l}\text { Segmental facial hemangioma accompanied by } \\
\text { brain anomalies: Report of a case }\end{array}$ \\
\hline Molecular Medicine Reports & $\begin{array}{l}\text { Department of Molecular Biology and } \\
\text { Biotechnology, Division of Human Genetics, } \\
\text { Atomic Energy Commission of Syria }\end{array}$ & 2012 & $\begin{array}{l}\text { Detailed analysis of an idic }(\mathrm{Y})(\mathrm{q} \mid \mathrm{I} .2 \mathrm{I}) \text { in a mosaic } \\
\text { karyotype }\end{array}$ \\
\hline $\begin{array}{l}\text { Saudi Journal of Kidney Disease and } \\
\text { Transplantation }\end{array}$ & $\begin{array}{l}\text { Pediatric Nephrology Department, Kidney } \\
\text { Hospital, Damascus, Syria }\end{array}$ & 2011 & $\begin{array}{l}\text { Spontaneous remission of posttransplant } \\
\text { recurrent focal and segmental glomerulosclerosis }\end{array}$ \\
\hline Canadian Journal of Rural Medicine & Faculty of Medicine, University of Aleppo & 2011 & Country cardiograms case 40 \\
\hline American Journal of Medical Genetics & $\begin{array}{l}\text { Human Genetics Division, Molecular } \\
\text { Biology and Biotechnology Department, } \\
\text { Atomic Energy Commission of Syria }\end{array}$ & 2011 & $\begin{array}{l}\text { A new case of de novo } \\
\text { translocation }(I 2 ; 17 ; 18)(\mathrm{q} 21.2 ; \mathrm{q} 22 ; \mathrm{q} 21 . \mathrm{I}) \text { and } \\
\text { cranio-cerebello-cardiac (3C) syndrome }\end{array}$ \\
\hline Dermatology Online Journal & Ministry of Health, Syria-Hama & 2009 & $\begin{array}{l}\text { Unknown: Erythematous nodules on the right } \\
\text { cheek and chin }\end{array}$ \\
\hline International Urology and Nephrology & Aleppo University & 2014 & $\begin{array}{l}\text { Central pontine and extrapontine myelinolysis } \\
\text { secondary to fast correction of severe hyponatremia } \\
\text { and hypokalemia in an alcoholic patient }\end{array}$ \\
\hline Turkish Journal of Pathology & $\begin{array}{l}\text { Department of Oral Pathology, Aleppo } \\
\text { University, Faculty of Dentistry }\end{array}$ & 2013 & $\begin{array}{l}\text { Immunohistochemical expression of p } 16 \text { in } \\
\text { pleomorphic salivary adenoma }\end{array}$ \\
\hline Molecular Medicine Reports & $\begin{array}{l}\text { Department of Molecular Biology and } \\
\text { Biotechnology, Division of Human Genetics, } \\
\text { Atomic Energy Commission of Syria }\end{array}$ & 2013 & $\begin{array}{l}\text { A unique case of female pseudohermaphroditism } \\
\text { with } 2 I \text {-hydroxylase deficiency and small } \\
\text { supernumerary marker chromosome } 7\end{array}$ \\
\hline Arab Journal of Gastroenterology & $\begin{array}{l}\text { Department of Gastroenterology, Saint } \\
\text { Louis Hospital, Aleppo, Syria }\end{array}$ & 2013 & $\begin{array}{l}\text { A rare cause of odynophagia and dysphagia: } \\
\text { Oesophageal lichen planus }\end{array}$ \\
\hline
\end{tabular}

A major concern was that our search of case reports missed several publications that met the study's inclusion criteria. This resulted in underreporting the total number of Syrian case reports. We admit that our methods missed mentioning the search end period. We would like to clarify that our search was open-dated in PubMed until July 2014, the date we started analyzing the data and preparing the manuscript. Therefore, case reports after this date were not counted in our study.

Moreover, other reason of miscounting some reports is that few case reports were published as reviews and not under case report category.

Using the same search time frame and expanding to other publication categories, we re-examined our search process and had found a number of other case reports. The total number of missed case reports was 14, which raises our results from 47 to 61 case reports published by Syrian medical personnel.

Despite miscounting these case reports, we believe that our comparison provided a valid conclusion since we used the same search methods, keywords, and publications timing for both countries compared in the study, Syria and Tunisia.

Another concern is that how could this article reflect medical students' productivity in medical research when only evaluated case reports published from Syria. This might have shown a discrepancy between the title, introduction, and conclusion from one side to the methods and results on the other side. To clarify: We were aiming to show what percentage of those published case reports included medical students among their author teams, but that was unfortunately not possible because most authors did not classify their academic degrees or positions. Nevertheless, the discussion section highlighted the importance of focusing on medical students as strategic and pivotal step to face the major deficiencies in Syrian medical research productivity [Table 1].

\section{Financial support and sponsorship}

Nil.

\section{Conflicts of interest}

There are no conflicts of interest. 


\begin{abstract}
Bassel Atassi
Clinical Assistant Professor of Medicine, Chicago Medical School, Internal Medicine, Hematology and Clinical Oncology, The Cancer Center at Little Company of Mary Hospital, Chicago, IL, USA
\end{abstract}

Address for correspondence: Dr. Bassel Atassi,

Wayne State University, Detroit, Michigan, USA. E-mail:mb_atassi@yahoo.com

This is an open access article distributed under the terms of the Creative Commons Attribution-NonCommercial-ShareAlike 3.0 License, which allows others to remix, tweak, and build upon the work non-commercially, as long as the author is credited and the new creations are licensed under the identical terms.

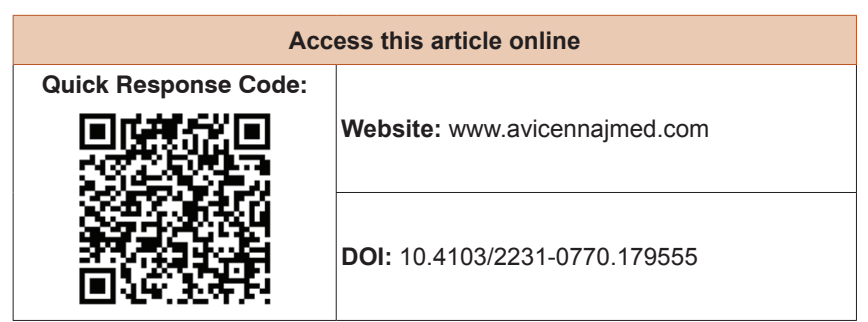

Cite this article as: Atassi B. Comments on: "Case reports and research productivity among Syrian medical students: Review, reality, and suggested solutions". Avicenna J Med 2016;6:61-3. 